\title{
Selective Prevention for Anxiety and Resilience Promotion: Outcomes of an Anxiety Prevention and Resilience Program with Girls at Risk
}

\author{
Julia Gallegos-Guajardo*, Norma A. Ruvalcaba-Romero ${ }^{\star *}$, Audra Langley ${ }^{\star * *}$, \\ Diana Villegas-Guinea ${ }^{* * *}$
}

\footnotetext{
Ph.D. University of Monterrey. Mexican Center for Emotional and Social Intelligence.

Correo electrónico:

julia.gallegos@udem.edu

** Ph.D. Department of Mental Health Clinics, University of Guadalajara.

Correo electrónico: nruval@hotmail.com

*** Ph.D. Semel Institute for Neuroscience and Human Behavior, University of California, Los Angeles.

Correo electrónico:

alangley@mednet.ucla.edu

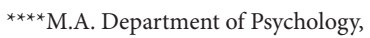

Universidad Iberoamericana.

Correo electrónico:

dianar.villegas@gmail.com
}

Recibido: 27 de febrero del 2015

Aprobado: 1 de junio del 2015

Cómo citar este artículo: Gallegos-Guajardo

J., Ruvalcaba-Romero, N. A., Langley, A.

\& Villegas-Guinea, D. (2015). Selective

Prevention for Anxiety and Resilience

Promotion: Outcomes of an Anxiety Prevention

and Resilience Program with Girls at Risk.

Pensando Psicología, 11(18), 11-23. doi:

http://dx.doi.org/10.16925/pe.v11i18.1001

\begin{abstract}
Introduction: Research has shown that the number of children and adolescents experiencing emotional difficulties such as anxiety is escalating, especially for those groups at risk. Living in an orphanage has been considered a risk factor for delays in an individuals' social, emotional and behavioral development. Objective: The aim of this study was to evaluate the effectiveness of the Spanish version of the FRIENDS program, a СВT-based resilience program, with 57 girls from low socioeconomic status (SES) background that were living in an orphanage. Method: Participants received the program for ten consecutive weeks, and pre- and post-test measures were collected. Measures evaluated participants' anxiety symptoms, level of self-concept, hope, coping skills, and psychosocial difficulties. Social validity was also assessed. Results: Results showed positive changes, including a decrease in anxiety symptoms and psychosocial difficulties, as well as an increase in their proactive coping skills. Several subscales and items of the self-concept and hope outcome measures also reported statistically significant improvements. Conclusions: Participants and parents/caregivers reported that the program was both enjoyable and useful. Implications of the findings and directions for further research are discussed.
\end{abstract}

Keywords: anxiety, cognitive-behavior program, orphanage resilience, prevention. 


\section{Prevención selectiva de la ansiedad y promoción de la resiliencia: resultados de un programa de resiliencia y prevención de la ansiedad con niñas en riesgo}

\section{Resumen}

Introducción: Las investigaciones han demostrado que el número de niños y adolescentes que experimentan dificultades emocionales como la ansiedad va en aumento, sobre todo para los grupos en situación de riesgo. Vivir en un orfanato se ha considerado un factor de riesgo de retraso en el desarrollo social, emocional y conductual de un individuo. Objetivo: El objetivo de este estudio era evaluar la eficacia de la versión en español del programa FRIENDS, un programa de resiliencia basado en la TCC, con 57 niñas de bajo nivel socioeconómico (NSE) que estaban viviendo en un orfanato. Método: Las participantes recibieron el programa durante diez semanas consecutivas y se recogieron las medidas previas y posteriores a la prueba. Las medidas evaluaban los síntomas de ansiedad, el nivel de autoconcepto, la esperanza, la capacidad de afrontamiento y las dificultades psicosociales de las participantes. También se evaluó la validez social. Resultados: Los resultados mostraron cambios positivos, incluyendo una disminución en los síntomas de ansiedad y las dificultades psicosociales, así como un aumento en su capacidad proactiva de afrontamiento. Varias subescalas y elementos de las medidas de resultado para autoconcepto y esperanza también reportaron mejorías estadísticamente significativas. Conclusiones: Las participantes y los padres/cuidadores informaron que el programa era agradable y útil. Se discuten las implicaciones de los hallazgos y las direcciones para futuras investigaciones.

Palabras clave: ansiedad, programa cognitivo-conductual, resiliencia en orfanatos, prevención.

\section{Prevenção seletiva da ansiedade e promoção da resiliência: resultados de um programa de resiliência e prevenção da ansiedade com meninas em risco}

\section{Resumo}

Introdução: as pesquisas têm demonstrado que o número de crianças adolescentes que experimentam dificuldades emocionais como a ansiedade vem aumentando, principalmente para os grupos em situação de risco. Viver num orfanato é considerado um fator de risco de atraso no desenvolvimento social, emocional e comportamental de um indivíduo. Objetivos: o objetivo deste estudo para avaliar a eficácia da versão em espanhol do programa FRIENDS, um programa de resiliência baseado na Terapia Cognitivo-comportamental, com 57 meninas de baixo nível socioeconômico que estavam morando num orfanato. Método: as participantes receberam o programa durante dez semanas consecutivas e foram coletadas medidas prévias e posteriores à prova. As medidas avaliavam os sintomas de ansiedade, o nível de autoconceito, a esperança, a capacidade de enfrentamento e as dificuldades psicossociais das participantes. Também foi avaliada a validade social. Resultados: os resultados mostraram mudanças positivas, o que inclui uma diminuição nos sintomas de ansiedade e das dificuldades psicossociais, bem como um aumento em sua capacidade proativa de enfrentamento. Várias subescalas e elementos das medidas de resultado para autoconceito e esperança também relataram melhoras estatisticamente significativas. Conclusões: as participantes e os pais/ cuidadores informaram que o programa era agradável e útil. Discutem-se as implicações dos achados e as direções para futuras pesquisas.

Palavras-chave: ansiedade, programa cognitivo-comportamental, resiliência em orfanatos, prevenção. 
Research has found that anxiety disorders are among the most common problems experienced by children and adolescents (American Psychiatric Association, 2013), with worldwide prevalence rates between $4 \%$ and 25\% (Neil \& Christensen, 2009), and an average of $8 \%$ (Boyd, Kostanski, Gullone, Ollendick, \& Shek, 2000; Cole, Peeke, Martin, Truglio \& Seroczynski, 1998; Tomb \& Hunter, 2004). A recent study indicated a high prevalence rate of $29,8 \%$ for any anxiety disorder in Mexican adolescents ages 12 to 17 (Benjet et al., 2009), with specific and social phobias as the most common type of anxiety disorder endorsed. The course of anxiety disorders is often chronic, and if left untreated, can be a risk factor for other problems such as school dropout, depression, and substance abuse (Donovan \& Spence, 2000). Therefore, it is critical to teach social and emotional skills to children and youth, especially those at risk, in order to increase their resilience and work toward the prevention of anxiety.

According to several authors, children and youth living in an orphanage setting are considered 'at risk' for delays in social, emotional, and behavioral development, including problems with anxiety (Ainsworth, 1965; Ahmad \& Mohamad, 1996; Boris, Thurman, Snider, Spencer, \& Brown, 2006; Johnson, 2000; Somen, 1986). It has been suggested that these deficits arise from difficulties experienced in the caregiver-child relationship, particularly in their attachment bond (McCabe \& Almatura, 2011). In orphanages, the quality of the child/adolescent interaction with the primary caregivers is not as frequent as needed and is often disrupted due to rotation in caregivers and a lesser amount of engaging time. As a consequence, the quality of their interpersonal interactions and the availability of an enriched learning environment are impaired (Rutter, Kreppner, \& O'Connor, 2011). The Center on the Developing Child at Harvard University (n. d.) explained that one of the most essential experiences in shaping the architecture of the developing brain is a responsive and dynamic relationship between children and significant adults, as well as the availability of supportive environments. In contrast, Bowlby suggested that if adult responses are unreliable, inappropriate, or simply absent, developing brain circuits can be disrupted, and insecure attachments could translate into future emotional and behavioral difficulties (1973).

The FRIENDS program is a resilience program, developed by Dr. Paula Barrett, which uses cognitive-behavioral techniques for the prevention and early intervention of anxiety. There are three developmentally tailored versions of the program: for children ages 4-7 (Barrett, 2011a; Barrett, 2011b); children ages 8-11 (Barrett, 2011c; Barrett, 2011d); and adolescents ages 12 to 16 (Barrett, 2011e; Barrett, 2011f). The program has been implemented in different countries and at all levels of prevention. For the selective level of prevention the following 'at risk' groups have been studied: non-English speaking immigrants; African American children who have been exposed to community violence; children and youth from socioeconomically disadvantaged communities; children who reported high levels of anxiety sensitivity; students exhibiting anxious symptomatology, low mood, and low self-esteem; and children living in an orphanage (Barrett, Moore, \& Sonderegger, 2000; Barrett, Sonderegger, \& Sonderegger, 2001; Barrett, Sonderegger, \& Xenos, 2003; Cooley-Quille, Boyd, \& Grados, 2004; Cooley-Strickland, Griffin, Darney, Otte, \& Ko, 2013; Gallegos, Rodríguez, Gómez, Rabelo, \& Gutiérrez, 2012; Liddle \& Macmillan, 2010; Siu, 2007; Stopa, Barrett, \& Golingi, 2010; TortellaFelliu, Servera, Balle, \& Fullana, 2004). In general, positive results have been reported after receiving the program such as: an increase in proactive coping skills, self-esteem, resilience, social skills, and positive future outlook. Results have also reported a decrease in anxiety and depressive symptoms, conflict with peers and conduct problems.

There are some studies that have implemented programs, which aim is to improve the physical conditions and the social and emotional development of children and youth living in orphanages (Ssewamala, Neilands, Waldfogel, \& Ismayilova, 2012; McCall et al., 2010; Schnek, 2009; Groark, Muhamedrahimov, Palmov, Nikiforova, \& McCall, 2005), but most of them were delivered to the caregivers, not to children. There are two studies that have implemented programs with the children. The study by Kumakech, Cantor-Graae, Maling and Bajunirwe (2009) evaluated the effect of a school-based peer-group support intervention, combined with periodic somatic health assessments and treatment on the psychological wellbeing of AIDS orphans from Uganda. Results showed that participants from the intervention group, in comparison with those from the control group, showed significant improvement in depression, anger and anxiety.

Gallegos et al. (2012) conducted a study to evaluate the effectiveness of the Spanish version of the FRIENDS for Life program with ten girls, ages 9 to 10 , 
living in a Mexican orphanage. Pre and post measures evaluated anxiety, depression, coping skills, self-concept, self-esteem and optimism. Results showed positive changes especially in their optimism and self-concept. Particular subscales and items also reported improvements such as a decrease in worry, physiological symptoms of anxiety, as well as a negative mood and an increase in self-esteem at home and with peers. Participants evaluated the program as enjoyable and useful; and they rated changing negative unhelpful thoughts to positive thoughts, and the coping step plan as particularly useful (Gallegos et al., 2012).

In order to extend current knowledge, the present study included a larger sample with a broader age range, and also included the evaluation of participants' psychosocial difficulties and social validity as rated by caregivers. Two research questions guided this study:

1. What is the effect of the Spanish version of the FRIENDS program on girls' anxiety, self-concept, hope, coping skills, and psychosocial difficulties? It was hypothesized that the self-concept, hope, proactive coping skills and pro-social behavior would increase; girls would report less anxiety symptoms and psychosocial difficulties after the intervention.

2. To what extent girls and their caregivers were satisfied with the program and which of the skills they found most useful? It was hypothesized that girls and caregivers would enjoy the program and would find the skills learned to be useful to cope with daily life stressors.

\section{Method}

A one group pre-test post-test design was employed to address the research questions. The independent variable was the Spanish version of the FRIENDS program and the dependent variables were anxiety, self-concept, hope, coping skills, and psychosocial difficulties. Social validity was also evaluated.

\section{Participants}

Participants were 57 girls, ages 5 to 15 years old, coming from a low socioeconomic background that were living in an orphanage in Mexico. The mean age of participants was $10.95(\mathrm{SD}=2.94)$. Girls were living in the orphanage for several reasons: some of them were abandoned by their parents or had lost their parents; some others came from dysfunctional families with situations such as drug abuse, physical and psychological abuse; and some have parents or close relatives that visit them on the weekends, but do not have the resources to take care of them at home. Participants in this study also included the caregivers, referring to the relative/parent who took care of them during the weekend. And for the ones that stayed all week in the orphanage, the caregiver was one of the nuns working in the place. The city chosen for this study is one of the three cities in Mexico with the highest prevalence rate for anxiety disorders (Medina-Mora et al., 2003).

\section{Measures}

Five measures were administered collectively to all participants to assess anxiety, self-concept, hope, coping skills and psychosocial difficulties. Social validity was also evaluated.

\section{Revised Children's Manifest Anxiety (Reynolds \& Richmond, 1985)}

Escala de Ansiedad Manifiesta en Niños Revisada (CMAR-R) is the Spanish version of the Revised Children's Manifest Anxiety Scale, a 37-item self-report measure of trait anxiety in children and adolescents ages 6 to 19. A total of 28 items pertain to trait anxiety, with a further of nine items assessing social desirability. Items are presented as a series of statements, which participants are required to endorse as being either true or not true of them, by indicating either "yes" (1) or "no" (0) respectively. A total score is derived by summing together the responses for each item, with a higher score indicating greater levels of anxiety. The scale has three anxiety subscales: physiological anxiety, worry, and social anxiety. The CMAR-R has sound psychometric properties including high internal consistency and moderate test-retest reliability (Reynolds \& Richmond, 1985). The CMAR-R has been validated with a Mexican population (Bautista, 2000), and shows acceptable psychometric properties: Cronbach's alpha coefficient between 0.67 and 0.74 (González, Ampudia, \& Guevara, 2012; Robles, 2008). A reliability index of $\alpha=0.663$ was found (Cronbach's Alfa) in this study. 


\section{Piers-Harris Children's Self-Concept Scale (Piers, 1984)}

Piers Harris 2: Lo Que Pienso de Mí Mismo is the Spanish version of the Piers-Harris Children's SelfConcept Scale that was designed to examine the self-attitudes of children ages 8-19. The self-reported measure assesses six aspects of a child's selfconcept: behavior, intellectual and school status, physical appearance and attributes, anxiety, popularity, and happiness and satisfaction. The instrument is a 60 -item inventory consisting of short sentences for which the child answers yes or no. The items describe children's feelings about themselves and about the reactions of others toward them; higher scores indicate a better self-concept. Each positive response is scored with 1 point and each negative response with 0 points. About half of the 60 statements indicate high self-concept and half are low selfconcept. High scores indicate a better self-concept. cscs total scale internal consistency ranges from 0.88 to 0.94 with stability ranging from 0.42 to 0.96 . Cscs subscale internal consistency ranges from 0.73 to 0.81 (Bracken, Bunch, Keith, \& Keith, 2000; Piers, 1984). Scores on the cscs have shown adequate test-retest reliability $(r=0.80)$ and convergent validity $(r=0.61)$ with other self-concept instruments such as Multidimensional Self-Concept Scale (Piers, 1984). A reliability index of $\alpha=0.938$ was found (Cronbach's Alfa) in this study.

\section{The Children's Hope Scale (Snyder et al., 1997)}

Is a self-report measure designed to measure children's dispositional hope. The measure was translated into Spanish for this study. The measure was developed for use with children 8-16 years and consists of six items, three of which assess agency thoughts and three of them assess pathways thoughts. In response to each item, the children are giving the 6-option continuum: "None of the time" to "All of the time", and are asked to select the option that describes them the best. A higher total score represents a higher level of hope. Snyder et al. (1997) have reported acceptable psychometric properties such as internal consistency $(r=0.77)$ and test-retest reliability $(r=0.73)$, as well as support for concurrent and predictive validity. A reliability index of $\alpha=0,787$ was found (Cronbach's Alfa) in this study.

\section{Coping Skills Questionnaire (Hernández- Guzmán, 2003)}

The questionnaire was developed and standardized in Mexico to assess coping skills in children. The Cuestionario de Afrontamiento is a self-report measure for children aged 6 to 12 years. The scale has twelve items related to child's interpretation and reactions when facing a problem, and the things he or she does to cope and/or solve the problem. Lower scores reflect a more proactive positive coping. Children are asked to rate, on a 3-point scale ranging from never (0) to always (2), the frequency with which they experience each statement. Scores of the Cuestionario de Afrontamiento have shown adequate psychometric properties (Hernández-Guzmán, 2003). The Cuestionario de Afrontamiento has demonstrated adequate psychometric properties including a Cronbach's alpha reliability coefficient of 0.67 (Hernández-Guzmán, 2003). A reliability index of $\alpha=0.531$ was found (Cronbach's Alfa) in this study.

\section{Strengths and Difficulties Questionnaire (SDQ) (Goodman, 1997)}

Cuestionario de Capacidades y Dificultades is the Spanish version of the Strengths and Difficulties Questionnaire. The SDQ-S is a 25 item self-report measure of psychological adjustment for use with children aged 11 to 17 years. The SDQ-P is completed also by parents or caregivers in order to evaluate psychosocial adjustment of children and adolescents aged 3 to 16 years. The items are divided between five scales: emotional symptoms, conduct problems, hyperactivity/inattention, peer relationship problems, and pro-social behaviour. Participants are required to endorse either "not true" (0), "somewhat true" (1), or "certainly true" (2), in response to each statement, with higher scores indicative of greater problems for each subscale except for pro-social behaviour. The SDQ-S has sound psychometric properties, including moderate to strong internal reliability for all subscales, good test-retest reliability (Vostanis, 2006), concurrent validity, and the ability to distinguish between community and clinical samples (Goodman, 2001). The measure has not been validated with Mexican population. However the validation, studies from Spain has shown acceptable psychometric properties: Cronbach's alpha coefficient for the total SDQ for students range between 0.77 and 0.87 , and the SDQ for parents/caregivers between 0.76 
and 0.83 (Rodríguez-Hernández, 2006; RodríguezHernández et al., 2012). A reliability index of $\alpha=0.731$ was found (Cronbach's Alfa) in this study.

\section{Social Validity Questionnaire for Children and Adolescents (Barrett, 2005)}

For this study, the questionnaire was translated into Spanish. The questionnaire is comprised of seven questions. Using a 4-point scale from 4 (a lot/all the time) to 1 (not at all/ nothing at all). The first five questions related to how enjoyable the program was, how much they learned by doing the program with their friends, how much they learned about feelings and about how to cope when being worried or upset, and how often they use the skills. The sixth question asked which skills did they found most useful, and a final open-ended question provided an opportunity to comment on the program.

\section{Social Validity Questionnaire for Parents/Ca- regivers (Barrett, 2005)}

For this study, the questionnaire was translated into Spanish. The questionnaire was comprised of eleven questions. The first nine questions used 4-point scale from 4 (a lot/all the time/very useful) to 1 (not at all/ nothing at all/not useful at all). Two of the questions asked how useful they thought positive coping-skills programs were and how important will it be to incorporate a program like this into the school curriculum. Two questions related to how useful the skills were to themselves and how much did they learn about enhancing their child/adolescent's coping skills. Four questions related to how much they thought their child/adolescent learnt about feelings and coping skills, how much they thought she or he enjoyed the program, and how often did she or he used the ideas and skills learnt in the program. Question 10 asked parents/caregivers to choose which skills their child/ adolescent found more useful, and question 11 was an open-ended asking to provide any other feedback (positive or negative) that they had.

\section{Procedure}

Measures were counterbalanced and administered to all participants at pre-test and post-test. Specifically, pre-test measures were administered three days before implementing the program and post-test measures three days after the program finished. Instructions and test items for all measures were read aloud and participants were informed that all responses are confidential.

The six group leaders that implemented the intervention completed a two-day training covering the principles and practices of prevention, along with an early intervention and a step-by-step guide to implement the FRIENDS program. The group leaders had a Bachelor in Psychology, and their age range was between 25 and 30 years old.

Eight groups were randomly formed taking into account age and each group was comprised of six to eight participants. There are three developmentally appropriate versions of the FRIENDS program. One developed for children from 4 to 7 years old, one for 8 to 11 years old, and one for adolescents from 12 to 16 years old. The groups were formed for each version of the program. When they were more than eight participants for a specific version, the group was divided to include participants from a closer age range (i.e. 10-11 years old). Group leaders implemented the program once a week for ten consecutive weeks. Sessions lasted 60 to 75 minutes and were conducted after school at the orphanage.

\section{Intervention protocol and materials}

Dr. Paula Barrett developed the FRIENDs program with the aim of increasing adaptive social and emotional skills, promoting resilience and preventing anxiety in children and youth. The program is based in cognitive-behavioral theory (Свт) and positive psychology. Based on efficacy research, Свт is now recommended as the gold standard for treating and preventing anxiety (Neil \& Christensen, 2009). It incorporates physiological, cognitive and behavioral strategies to assist children in coping with stress and worry. The behavioral component includes self-monitoring of feelings and thoughts, out-of-session, mental imagery exposure and relaxation training. The cognitive component teaches children to recognize their feelings and thoughts, along with the link between them. It also teaches students to identify faulty cognitions and incompatible self-statements, and to elaborate alternative interpretations for difficult situations. The family and peer support component discourages the avoidance of anxiety-provoking situations by promoting the practice of problem solving. It encourages the building of social support groups and respect for diversity. Learning techniques include group discussion, hands-on activities and 
role-play. Approximately, one session is dedicated to learn each of the seven steps represented by the FRIENDS acronym. The Spanish acronym is parallel to the English in terms of the concepts taught. After the introductory session, children start to learn the letter $F$, which stands for "Feeling worried?"; followed by the letter R: "Relax and feel good"; $I$ : "Inner helpful thoughts"; E: "Explore solutions and coping plans"; $N$ : "Nice work; reward yourself"; $D$ : "Don't forget to practice"; and $S$ : "Smile and stay calm". Within each session, the teacher uses modeling of the skills, and after the skills are taught, children have opportunities to practice in small groups and debrief with the whole classroom. The program has three developmentally appropriate versions in Spanish, each of which were used in the current study: AMISTAD y Diversion for children ages 4-7 (Barrett, 2011a; Barrett, 2011b); AMISTAD para Siempre for children ages 8-11 (Barrett, 2011d; Barrett, 2011e); and Programa de Resiliencia para Adolescentes for adolescents ages 12-16 (Barrett, 2011d; Barrett, 2011f).

\section{Statistical analysis}

Questions were addressed separately using paired sample $t$-tests (alpha level 0,05$)$ in order to examine the dependent variables of anxiety, self-concept, hope, coping skills, and psychosocial difficulties. Means, standard deviations, and frequencies were calculated for each item of the social validity questionnaires.

\section{Results}

\section{Effects of the program}

To examine the effect of the intervention, participants' total scores and subscales on each outcome measure were compared from pre-test to post-test. Table 1 displays the means and standard deviations on each dependent measure at each time point, as well as t-test significance pre-post intervention.

The results showed that all the subscales of the anxiety measure, CMAS-R, as well as the total score, reported a statistically significant decrease after receiving the program. A statistically significant improvement was also found on girls' proactive copings skills. In the same way, the Strengths and Difficulties Questionnaire answered by caregivers also reported statistically significant improvements. The subscales of Physical Appearance and Attributes and Popularity of the Piers Harris Children's Self-Concept Scale 2 also reported a statistically significant increase.

Table 1

Means and SD for the R-CMAS, Self-Concept, Hope, Coping Skills and SDQ at Each Time Point

\begin{tabular}{|c|c|c|c|c|c|c|c|c|}
\hline \multirow{2}{*}{ Outcome Measure } & \multicolumn{3}{|c|}{ Pre-test } & \multicolumn{3}{|c|}{ Post-test } & \multirow{2}{*}{ t value } & \multirow{2}{*}{$\mathrm{p}$ value } \\
\hline & M & SD & $\mathrm{n}$ & M & SD & $\mathbf{n}$ & & \\
\hline CMAS-R & 15.93 & 4.60 & 41 & 11.90 & 5.88 & 41 & $5.97^{* *}$ & 0 \\
\hline Physiological Anxiety subscale (1) & 5.02 & 2.09 & 41 & 3.66 & 2.36 & 41 & $4.19^{\star *}$ & 0 \\
\hline Social Anxiety subscale & 7.07 & 1.92 & 41 & 5.68 & 2.63 & 41 & $4.18^{* *}$ & 0 \\
\hline Worry subscale & 3.73 & 1.9 & 41 & 2.44 & 1.95 & 41 & $4.36^{* *}$ & 0 \\
\hline Piers Harris Children's Self-Concept Scale 2 & 55.02 & 18.12 & 42 & 58.60 & 16.11 & 42 & -1.29 & 0.204 \\
\hline Behavioral Adjustment subscale & 44.29 & 6.56 & 42 & 45.50 & 7.04 & 42 & -1.19 & 0.24 \\
\hline Intellectual and School Status subscale & 45.86 & 10.70 & 42 & 46.98 & 9.59 & 42 & -0.77 & 0.446 \\
\hline $\begin{array}{l}\text { Physical Appearance and Attributes } \\
\text { subscale }\end{array}$ & 43.6 & 8.7 & 42 & 46.71 & 8.56 & 42 & $-2.13^{*}$ & 0.039 \\
\hline Freedom from Anxiety & 42.33 & 8.74 & 42 & 44.64 & 8.85 & 42 & -1.77 & 0.084 \\
\hline Popularity subscale & 46.71 & 8.57 & 42 & 49.95 & 9.59 & 42 & $-2.13^{*}$ & 0.039 \\
\hline Happiness and Satisfaction subscale & 38.31 & 7.06 & 42 & 40.05 & 5.92 & 42 & -1.58 & 0.121 \\
\hline The Children's Hope Scale & 22.45 & 6.81 & 49 & 23.57 & 6.92 & 49 & -1.41 & 0.221 \\
\hline Proactive Coping Skills Questionnaire & 10.68 & 2.84 & 28 & 9.36 & 2.80 & 3.18 & $2.36^{*}$ & 0.025 \\
\hline
\end{tabular}




\begin{tabular}{|c|c|c|c|c|c|c|c|c|}
\hline \multirow{2}{*}{ Outcome Measure } & \multicolumn{3}{|c|}{ Pre-test } & \multicolumn{3}{|c|}{ Post-test } & \multirow{2}{*}{$\mathrm{t}$ value } & \multirow{2}{*}{ p value } \\
\hline & $M$ & $S D$ & $n$ & $M$ & $S D$ & $n$ & & \\
\hline SDQ-Student version & 12.52 & 5.14 & 21 & 10.57 & 4.64 & 21 & 1.70 & 0.104 \\
\hline Emotional Symptoms subscale & 3.38 & 2.15 & 21 & 2.43 & 1.77 & 21 & 1.71 & 0.101 \\
\hline Conduct Problems subscale & 2.52 & 1.5 & 21 & 2.14 & 1.23 & 21 & 0.93 & 0.365 \\
\hline Hiperactivity/Innatention subscale & 4.57 & 2.54 & 21 & 4.05 & 2.55 & 21 & 0.98 & 0.341 \\
\hline Peer Relations Problems susbcale & 2.05 & 1.49 & 21 & 1.95 & 1.74 & 21 & 0.26 & 0.8 \\
\hline Pro-social behaviour subscale & 6.76 & 1.7 & 21 & 6.71 & 2.14 & 21 & 0.10 & 0.919 \\
\hline SDQ -Caregiver version & 14.70 & 6.21 & 47 & 12.79 & 6.05 & 47 & $2.27^{\star}$ & 0.028 \\
\hline Emotional Symptoms subscale & 4.17 & 2.58 & 47 & 3.23 & 2.11 & 47 & $2.42^{*}$ & 0.02 \\
\hline Conduct Problem subscale & 3.51 & 2.13 & 47 & 2.83 & 1.93 & 47 & $2.58^{*}$ & 0.013 \\
\hline Hiperactivity/Innatention subscale & 4.23 & 2.49 & 47 & 3.98 & 2.08 & 47 & 0.76 & 0.452 \\
\hline Peer Relations Problems susbcale & 2.79 & 1.75 & 47 & 2.79 & 1.8 & 47 & 0.01 & 1 \\
\hline
\end{tabular}

Note. ${ }^{*} \mathrm{p}<0.05,{ }^{* *} \mathrm{p}<0.01$. Compiled by the authors.

Pair samples $t$-tests were also conducted on the items of each outcome measure. The items that reported statistically significant differences were the following. From the Piers Harris Children's SelfConcept Scale 2, item 30 My parents expect a lot from me, $t(41)=-2.72, p<0.05$. From the Children's Hope Scale, the item 6 Even when others want to quit, I know I can find ways to solve the problem, $t(48)=$ $-2.60, p<0.05$. From the Strengths and Difficulties Questionnaire answered by girls, item 21 I think before I do things, $t(20)=4.26, p<0.05$.

Table 2

Participants' means for each of the items of the Social Validity Questionnaire

\begin{tabular}{lccc}
\hline \multicolumn{1}{c}{ Question } & N & Mean & SD \\
\hline $\begin{array}{l}\text { How much did you enjoy the } \\
\text { FRIENDs program? }\end{array}$ & 52 & 3.79 & 0.50 \\
$\begin{array}{l}\text { How much did you learn about } \\
\text { feelings? }\end{array}$ & 51 & 3.61 & 0.72 \\
$\begin{array}{l}\text { How much did you learn by doing } \\
\text { the program with your friends? }\end{array}$ & 51 & 3.59 & 0.67 \\
$\begin{array}{l}\text { How much did you learn about } \\
\text { how to cope with feeling worried } \\
\text { or upset? }\end{array}$ & 52 & 3.46 & 0.96 \\
$\begin{array}{l}\text { How often do you use the ideas } \\
\text { and skills learned in the FRIENDs } \\
\text { program? }\end{array}$ & 52 & & \\
\hline
\end{tabular}

Note. 4 A lot / All the time, 1 Not at All/ Nothing at All. Compiled by the authors.

\section{Social Validity Evaluation}

Girls and caregivers also completed a social validity evaluation with the purpose of knowing their opinion about how enjoyable and useful the program was. Table 3 displays the girls' responses to questions regarding how much they enjoyed the program, how much they learned, and how often they practice the ideas and skills learned in the program. Overall, girls evaluated the program as enjoyable and helpful to cope with difficult situations; $94 \%$ indicated that they enjoyed the program, and $88.7 \%$ reported that they used the skills learned.

Table 3

Participants' ratings of the skills they found most useful

\begin{tabular}{lc}
\hline Skill & $\begin{array}{c}\text { Overall } \\
\%(n)\end{array}$ \\
\hline Relaxation exercises & $84.6 \%(44)$ \\
Helping others to feel good & $82.7 \%(43)$ \\
Recognizing feelings in others & $78.8 \%(41)$ \\
Step plan & $78.8 \%(41)$ \\
Thinking helpful thoughts & $76.9 \%(40)$ \\
Changing negative thoughts to positive & $76.9 \%(40)$ \\
thoughts & $76.9 \%(40)$ \\
Recognizing feelings in yourself & $73.1 \%(38)$ \\
6-Block problem solving plan & $71.2 \%(37)$ \\
Deep breathing & \\
\hline
\end{tabular}

Note. Compiled by the authors. 
Frequencies and percentages of the skills that girls found most useful appear in Table 4. The two coping skills that they found most useful were Relaxation exercises (84.6\%), and Helping others feel good (82.7\%). The two skills taught that they found least useful (although still relatively useful) were Deep breathing (71.2\%), and The six-block problem solving plan (73.1\%).

Table 5 displays the caregivers' responses on each of the items of the social validity questionnaire. Overall, they reported that the program was useful for them and for their children/adolescents; $96 \%$ indicated that they learned about enhancing their child/ adolescents' coping skills and $80 \%$ reported that the program was useful for this.

Frequencies and percentages of the skills caregivers found most useful for their children/adolescents appear in Table 6 . The two coping skills that they found most useful were Changing negative thoughts to positive thoughts (81.1\%), and Recognizing feelings in yourself (75.7\%). The two skills taught they found least useful were the Six-block problem solving plan (32.4\%), and Relaxation exercises (36.8\%). Results from the social validity questionnaires suggested that the program was, in general, well received by the girls living in the orphanage and the caregivers.

Table 4

Caregivers' means for each of the items of the Social Validity Questionnaire

\begin{tabular}{lccc}
\hline \multicolumn{1}{c}{ Question } & $N$ & Mean & SD \\
\hline $\begin{array}{l}\text { How useful do you think positive } \\
\text { coping-skills programs are in general? }\end{array}$ & 40 & 4.00 & 0.01 \\
$\begin{array}{l}\text { How important do you think it is that } \\
\text { your child's school incorporates a } \\
\text { program like this into the curricu- }\end{array}$ & 38 & 3.97 & 0.16 \\
$\begin{array}{l}\text { lum? } \\
\begin{array}{l}\text { How much did you learn about } \\
\text { enhancing your child's coping-skills? }\end{array}\end{array}$ & 38 & 3.79 & 0.47 \\
$\begin{array}{l}\text { How much do you think your child } \\
\text { learned about understanding feelings }\end{array}$ & 40 & 3.78 & 0.57 \\
in themselves and others? & & & \\
$\begin{array}{l}\text { How useful do you find the FRIENDs } \\
\text { program for enhancing your child's } \\
\text { coping skills? }\end{array}$ & 40 & 3.70 & 0.52 \\
$\begin{array}{l}\text { How much do you think your child } \\
\text { learned about coping with these } \\
\text { feelings? }\end{array}$ & 40 & 3.70 & 0.52 \\
$\begin{array}{l}\text { How much do you think your child } \\
\text { enjoyed the FRIENDs program? }\end{array}$ & 39 & 3.69 & 0.52 \\
\hline
\end{tabular}

\begin{tabular}{lccc}
\hline \multicolumn{1}{c}{ Question } & $N$ & Mean & SD \\
\hline $\begin{array}{l}\text { How often does your child use the } \\
\text { ideas (skills) that they learned in the }\end{array}$ & 36 & 3.56 & 0.61 \\
$\begin{array}{l}\text { FRIENDs program? } \\
\begin{array}{l}\text { How often do you use the ideas } \\
\text { (skills) that you learned in the }\end{array}\end{array}$ & 37 & 3.38 & 0.72 \\
FRIENDs program? & & & \\
\hline
\end{tabular}

Note. 4 Very useful/Very Important/A lot/All the time, 1 Not at all Useful/Not at all Important/Nothing at All/Not at All. Compiled by the authors.

Table 5

Caregivers' ratings of the skills their child found most useful

\begin{tabular}{lc}
\hline \multicolumn{1}{c}{ Skill } & $\begin{array}{c}\text { Overall } \\
\%(n)\end{array}$ \\
\hline $\begin{array}{l}\text { Changing negative thoughts to positive } \\
\text { thoughts }\end{array}$ & $81.1 \%(30)$ \\
Recognizing feelings in yourself & $75.7 \%(28)$ \\
Helping others to feel good & $70.3 \%(26)$ \\
Recognizing feelings in others & $67.6 \%(25)$ \\
Thinking helpful thoughts & $64.9 \%(24)$ \\
Deep breathing & $51.4 \%(19)$ \\
Step plan & $48.6 \%(18)$ \\
Relaxation exercises & $36.8 \%(14)$ \\
6-Block problem solving plan & $32.4 \%(12)$ \\
\hline
\end{tabular}

Note. Compiled by the authors.

\section{Discussion}

Being institutionalized in an orphanage has been linked to a series of negative psychological and social consequences (González et al., 2012) such as: the development of insecure attachment, lack of impulse control, low self-esteem, conflict in interpersonal relationships (Martínez, Rosete, \& de los Ríos, 2007), a higher external locus of control, lower perception of self-competency, higher perception of family difficulties, and a negative and avoidant coping style (González, Valdez, Domínguez, Palomar, \& González, 2008). Despite these elevated risks for negative outcomes, there has been a dearth of research related to preventive interventions for anxiety and psychosocial difficulties among children living in orphanages, particularly in Latin American countries such as Mexico.

This study investigated the effectiveness of the Spanish version of the FRIENDs program, used as a selective prevention strategy with girls living in an orphanage. The purpose was to examine whether the 
program produced any changes in anxious symptoms and psychosocial difficulties, as well as changes in the protective factors of self-concept, hope, coping skills and pro-social behavior. Satisfaction with the program was also assessed.

A positive and statistically significant change was found for anxiety, with girls reporting lower levels of anxious symptomatology after receiving the program. This is similar to what has been found with other 'at risk' population such as: immigrants in Australia, African-American youth exposed to violence, low SES children and youth in the United States, and Chinese children identified at risk for developing internalizing disorders (Cooley-Quille et al., 2004; Siu, 2007; Stopa et al., 2010). Several of the core components of the FRIENDS program include anxiety reduction techniques such as relaxation exercises, cognitive restructuring, and in vivo gradual behavioral exposure. Therefore, learning these techniques may have helped them to decrease their anxious symptoms. This idea is also supported by the social validity results, as Relaxation exercises was rated by girls as the most useful skill learnt in the program.

Improvements were also observed in the Piers Harris subscales of Physical Appearance and Attributes, and Popularity. Other studies have reported changes in similar areas. For example, when implementing the FRIENDS program with children who had recently immigrated to Australia, a couple studies reported improvement in participants' levels of self-esteem and reduced peer victimization (Barrett et al., 2001; Barrett et al., 2003). In the same way, current results as similar to those were found by Gallegos et al. (2012), who reported that after receiving the program, their participants' reported improvements in the Home and Social Self-esteem subscales of the Coppersmith Self-Esteem Inventory. These improvements are in line with the components of the FRIENDS program that target learning about empathy, self-respect and assertiveness, and social skills that promote positive relationships.

Girls from the current study - after receiving the program-reported statistically significant increases in their proactive coping skills, as they were better able to cope with anxiety-provoking situations and reduced their avoidance behaviors. This is similar to what has been found in other studies such as the ones conducted by Gallegos et al., (2012), and Stopa et al. (2010). This may be the result of learning different coping strategies such as positive thinking, relaxation and gradual exposure coping plans.
Caregivers reported reductions in girls' emotional and conduct problems and higher levels of pro-social behavior. Interestingly, both caregivers and girls reported that Helping others to feel good was one of the most useful skills they learned. This may be a reflection of culture, as socializing, cooperating and helping others are highly valued in Latin-American societies. Therefore, incorporating altruistic activities within their regular routines could also be potentially beneficial to increase children's own happiness and wellbeing.

Contrary to our original hypothesis, and to the findings of Barrett, Sonderegger and Xenos (2003), the current study did not find differences in the levels of optimism. A possible explanation could be that measure was not sensitive enough to evaluate optimism in children being reared in Mexican culture, as it had not been previously validated in this population. It could also be the case that, due to the specific characteristics of our participants, the program would need to be adapted in a more culture-specific and contextually relevant way, for those children living in an orphanage setting. These children may be dealing with significant issues of child traumatic stress, grief and loss, in order to create movement on this variable of optimism and hope. Thus, future research should examine the impact of refined contextualization of the program.

Also contrary to hypothesis, girls' scores on the SDQ did not indicate statistically significant changes. One possible explanation could be a desirability effect, in which the girls participating in the study could have elevated their evaluations of themselves at baseline, supported by the idea that children and youth in institutionalized care may have an increased need for approval (González et al., 2008).

\section{Limitations and future directions}

Although this study has included a larger sample size $(\mathrm{n}=57)$ than the previous study (Gallegos et al., 2012), the sample size still limits the power to reach statistical significance and future research would benefit from larger sample sizes within a similar population. It should also take into account the low reliability indices reported for two of the measures: CMAS-R and Coping Skills Questionnaire.

In terms of the design of the study, the current study lacks a control/comparison group which was precluded in the current study due to time and financial constraints, and to the particular characteristics 
of the setting. Because of this, a potential threat to internal validity exists because we cannot confirm if the difference between pre-test and post-test scores is related to the intervention, or to the maturation and history of participants. Threats to construct validity could have occurred such as the "mono-method bias", as for all variables self-reported measures were used. Also novelty of the intervention could have prompt participants to respond unusually well to the program (Shadish, Cook, \& Campbell, 2002).

It is recommended that a larger study be conducted with a control/comparison condition. While the current study included caregivers as additional informants, it would be additive to also include teacher reports in future studies as well as to evaluate the effectiveness of program for both genders.

Neil and Christensen (2009) have suggested that the biggest effect sizes for anxiety prevention and early intervention programs are seen for high-risk groups. Clearly then, young people living in orphanages both:

1. Have an urgent need to improve adaptive socialemotional skills and increase their resilience.

2. Are best able to recognize substantial benefits from such interventions.

Resilience has been related to a number of different positive outcomes such as decreasing the risk for experiencing psychopathology, better physical and mental health, and higher levels of happiness and subjective wellbeing (Friborg, Hjemdal, Rosenvinge, \& Martinussen, 2003).

Particularly for children and youth living in an orphanage, a high level of resilience seems to be almost a requirement to thrive (Ahmad \& Mohamad, 1996; Somen, 1986). Future studies should delve further into the social and emotional development of these vulnerable children and youth in order to identify which specific mechanisms will increase their resilience and assist in providing them the most enriching, stable and nurturing environment possible. In order to produce a meaningful and sustainable change, one important direction should include an emphasis on building resilience and emotional intelligence in caregivers. This may be particularly important for young people living in an orphanage as they may not have had positive adult role models, and the adults in their lives can serve as critical change agents for these vulnerable children (Center on the Developing Child at Harvard University, n. d.). It is very likely that the program will be more effective and gains will be more likely to be maintained over time if it also focuses on building capabilities in significant adults. Parents and caregivers, especially those living in the orphanage with the children, have the capacity to meet critical social and emotional needs (Groark et al., 2005; McCall et al., 2010).

\section{References}

Ahmad, A., \& Mohamad, K. (1996). The socioemotional development of orphans in orphanages and traditional foster care in Iraqi Kurdistan. Child Abuse \& Neglect, 20, 1161-1173. doi: 10.1016/S0145-2134(96)00067-1

Ainsworth, M. D. S. (1965). Further research into the adverse effects of maternal deprivation. In J. Bowlby (Ed.), Child care and the growth of love (pp.191-251). Baltimore: Penguin Publishers.

American Psychiatric Association (2013). DSM-V-TR. Diagnostic and statistical manual of mental disorders. Washington, D.C.: American Psychiatric Association.

Barrett, P. (2005). Support Materials for the FRIENDS program. Brisbane, Australia: Pathways Health and Research Centre.

Barrett, P. (2011a). AMISTAD y Diversión: Guía del instructor a base de juegos para crear resiliencia en niños de 4 a 7 años de edad. Brisbane, Australia: Barrett Research Resources Pty Ltd.

Barrett, P. (2011b). AMISTAD y Diversión: Guía para padres a base de juegos para crear resiliencia en niños de 4 a 7 años de edad. Brisbane, Australia: Barrett Research Resources Pty Ltd.

Barrett, P. (2011c). AMISTAD para Siempre: Cuaderno de Trabajo para Niños. Brisbane, Australia: Barrett Research Resources Pty Ltd.

Barrett, P. (2011d). AMISTAD para Siempre: Manual de líder de grupo para niños. Brisbane, Australia: Barrett Research Resources Pty Ltd.

Barrett, P. (2011e). Amistad Programa de Resiliencia para Adolescentes: Manual de líder de grupo. Brisbane, Australia: Barrett Research Resources Pty Ltd.

Barrett, P. (2011f). AMISTAD Programa de Resiliencia para Adolescentes: Cuaderno de Trabajo para Adolescentes. Brisbane, Australia: Barrett Research Resources Pty Ltd.

Barrett, P.M., Moore, A.F., \& Sonderegger, R. (2000). The FRIENDS program for young former-Yugoslavian refugees in Australia: A pilot study. Behaviour Change, 17, 124-133. 
Barrett, P.M., Sonderegger, R., \& Sonderegger, N.L. (2001). Evaluation of an anxiety-prevention and positive-coping program (FRIENDS) for children and adolescents of non-English speaking background. Behaviour Change, $18,78-91$.

Barrett, P.M., Sonderegger, R., \& Xenos, S. (2003). Using FRIENDS to combat anxiety and adjustment problems among young migrants to Australia: A national trial. Clinical Child Psychology and Psychiatry, 8, 241-260.

Bautista, V. (2000). Validez y confiabilidad de la escala de ansiedad manifiesta en niños y adolescentes mexicanos. (Unpublished Psychiatry Thesis, Universidad Nacional Autónoma de México, México).

Benjet, C., Borges, G., Medina-Mora, M., Zambrano, J., \& Aguilar-Gaxiola, S. (2009). Youth mental health in a populous city of the developing world: Results from the Mexican adolescent health survey. Journal of Child Psychology and Psychiatry, 50, 386-395. doi: 10.1111/j.1469-7610.2008.01962.x.

Boris, N., Thurman, T., Snider, L., Spencer, E., \& Brown, L. (2006). Infants and young children living in youthheaded households in Rwanda: Implications of emerging data. Infant Mental Health Journal, 27(6), 584-602.

Bowlby, J. (1973). Attachment and loss: Separation: anxiety and anger. New York: Basic Books.

Boyd, C. P., Kostanski, M., Gullone, E., Ollendick, T. H., \& Shek, D. T. L. (2000). Prevalence of anxiety and depression in Australian adolescents: Comparisons with worldwide data. The Journal of Genetic Psychology, 161, 479-492.

Bracken, B. A., Bunch, S., Keith, T. Z., \& Keith, P. B. (2000). Child and adolescent multidimensional self-concept: A five instrument factor analysis. Psychology in the Schools, 37(6), 483-493.

Center on the Developing Child at Harvard University (n. d.). In Brief: The Science of Neglect. Retreived from http://developingchild.harvard.edu/resources/briefs/ inbrief_series/inbrief_neglect/

Cole, D. A., Peeke, L. G., Martin, J. M., Truglio, R., \& Seroczynski, A. D. (1998). A longitudinal look at the relation between depression and anxiety in children and adolescents. Journal of Consulting and Clinical Psychology, 66, 451-460.

Cooley-Quille, M., Boyd, R. C., \& Grados, J. J. (2004). Feasibility of an anxiety prevention intervention for community violence exposed children. Journal of Primary Prevention, 25, 105-123. doi:10.1023/B:JOPP.0000039941.85452.ea
Cooley-Strickland, M. R., Griffin, R. S., Darney, D., Otte, K., \& Ko, J. (2013). Urban African American youth exposed to community violence: A school-based anxiety preventive intervention efficacy study. Journal of Prevention and Intervention in the Community, 39, 149 166. doi: 10.1080/10852352.2011.556573

Donovan, C. L. \& Spence, S. H. (2000). Prevention of childhood anxiety disorders. Clinical Psychology Review, 20, 509-531.

Friborg, O., Hjemdal, O., Rosenvinge, J. H., \& Martinussen, M. (2003). A new rating scale for adult resilience: What are the central protective resources behind healthy adjustment? International Journal of Methods in Psychiatric Research, 12(2), 65- 76.

Gallegos, J., Rodríguez, A., Gómez, G., Rabelo, M., \& Gutiérrez, M. F. (2012). The FRIENDs for Life program for Mexican girls living in an orphanage: A pilot study. Behaviour Change, 29, 1-14. doi:10.1017/bec.2012.8

Goodman, R. (1997). The Strengths and Difficulties Questionnaire: A research note. Journal of Child Psychology and Psychiatry, 38, 581-586. doi: 10.1111/ j.1469-7610.1997.tb01545.x

Goodman, R. (2001). Psychometric properties of the Strengths and Difficulties Questionnaire. Journal of the American Academy of Child \& Adolescent Psychiatry, 40, 1337-1345. doi: 10.1097/00004583-200111000-00015

González, C., Ampudia, A., \& Guevara, Y. (2012). Programa de intervención para el desarrollo de habilidades sociales en niños institucionalizados. Acta Colombiana de Psicología, 15(2), 43- 52.

González, I., Valdez, J., Domínguez, A., Palomar, J., \& González, S. (2008). Características psicosociales en niños en contextos de riesgo y de no riesgo. Persona, 11, 92-107.

Groark, C. J., Muhamedrahimov, R. J., Palmov, O. I., Nikiforova, N. V., \& Mccall, R. B. (2005). Improvements in early care in Russian orphanages and their relationship to observed behaviors. Infant Mental Health Journal, 26, 96-109. doi: 10.1002/imhj.20041

Hernández-Gúzman, L. (2003). Escala de afrontamiento (versión infantil). Proyecto de investigación DGAPA IN302600, evaluación y categorización de los trastornos de ansiedad en niños y adolescentes. México, D.F.: Universidad Autónoma de México.

Johnson, D. E. (2000). Medical and developmental sequel of early childhood institutionalization in Eastern European adoptees. In C. A. Nelson (Ed.), The effects of early adversity on neurobehavioral development: The Minnesota symposia on child psychology (pp. 113-162). Mahwah, NJ: Lawrence Erlbaum Associates. 
Kumakech, E., Cantor-Graae, E., Maling, S., \& Bajunirwe, F. (2009). Peer-group support intervention improves the psychosocial well-being of AIDs orphans: Cluster randomized trial. Social Science \& Medicine, 68, 10381043. doi: 10.1016/j.socscimed.2008.10.033

Liddle, I., \& Macmillan, S. (2010). Evaluating the FRIENDS program in a Scottish setting. Educational Psychology in Practice, 26, 53-67. doi:10.1080/02667360903522785

Martínez, P., Rosete, M., \& De los Ríos, R. (2007). Niños de la calle: Autoestima y funcionamiento yoico. Enseñanza e investigación en Psicología, 12(2), 367-384.

McCabe, P. C., \& Altamura, M. (2011). Empirically valid strategies to improve social and emotional competence of preschool children. Psychology in the Schools, 48, 513-540. doi:10.1002/pits.20570

McCall, R. B., Groark, C. J., Fish, L., Harkins, D., Serrano, G., \& Gordon, K. (2010). A socioemotional intervention in a Latin American orphanage. Infant Mental Health Journal, 31, 521- 542. doi: 10.1002/imhj.20270

Medina-Mora, M. E., Borges, G., Lara, C., Benjet, C., Blanco, J., Fleiz, C., Aguilar, S. (2003). Prevalencia de trastornos mentales y uso de servicios: resultados de la encuesta nacional de epidemiología psiquiátrica en México. Salud Mental, 26(4), 1-16.

Neil, A. J., \& Christensen, H. (2009). Efficacy and effectiveness of school-based prevention and early intervention programs for anxiety. Clinical Psychology Review, 29, 208-215. doi: 10.1016/j.cpr.2009.01.002

Piers, E. V. (1984). Piers-Harris Children's Self-Concept Scale: Revised Manual. Los Angeles: Western Psychological Services.

Reynolds, C. R., \& Richmond, B. O. (1985). The Revised Children's Manifest Anxiety Scale: Manual. New York: Western Psychological Services.

Robles, J. A. (2008). Salud mental de menores en edad escolar en los campos agrícolas de Sonora. (Unpublished Master's Thesis, Centro de Investigación en Alimentación y Desarrollo, A. c., México).

Rodríguez-Hernández, P. J. (2006). Estudio de la prevalencia de los trastornos psiquiátricos infantiles en la Comunidad Autónoma Canaria. (Unpublished Doctoral's Thesis, Universidad de la Laguna, Departamento de Medicina Interna, Dermatología y Psiquiatría, España).

Rodríguez-Hernández, P. J., Betancort, M., Ramírez-Santana, G.M., García, R., Sanz-Álvarez, E. J., \& De las CuevasCastresana, C. (2012). Psychometric properties of the parent and teacher versions of the Strenght and Difficulties Questionnaire (SDQ) in a Spanish sample. International Journal of Clinical and Health Psychology, 12(2), 265- 279.
Rutter, M., Krepper, J. M., \& O’Connor, T. G. (2011). Specifity and heterogeneity in children's responses to profound institutional privation. The Journal of Mental Science, 179, 97-103. doi: 10.1080/17405620701401846

Shadish, W. R., Cook, T. D., \& Campbell, D. T. (2002). Experimental and cuasi-experimental designs for generalized causal inference. Boston: Houghton Mifflin Company.

Schnek, K. D. (2009). Community interventions providing care and support to orphans and vulnerable children: A review of evaluation evidence. AIDS Care, 21(7), 918942.

Siu, A. F. Y. (2007). Using FRIENDs to combat internalizing problems among primary school children in Hong Kong. Journal of Cognitive and Behavioral Psychotherapies, 7, 11-26. Retrieved from http://jebp. psychotherapy.ro/vol7no1/using-friends-to-combatinternalizing-problems-among-primary-school-children-in-hong-kong/

Somen, K. S. (1986). A study of the mental health status of children in orphanages at Bangalore. Indian Journal of Social Work ,5, 137-146.

Snyder, C. R., Hoza, B., Pelham, W. E., Rapoff, M., Ware, L., Danovsky, M., ... Stahl, K. J. (1997). The development and validation of the Children's Hope Scale. Journal of Pediatric Psychology, 22(3), 399-421.

Ssewamala, F. M, Neilands, T. B., Waldfogel, J., \& Ismayilova, L. (2012). The impact of a comprehensive microfinance intervention on depression levels of AIDS-orphaned children in Uganda. Journal of Adolescent Health, 50, 346- 352. doi: 10.1016/j.jadohealth.2011.08.008

Stopa, E. J., Barrett, P. M., \& Golingi, F. (2010). The prevention of childhood anxiety in socioeconomically disadvantaged comunities: A universal school based trial. Advances in School Mental Health Promotion, 3(4), 5-24.

Tomb, M., \& Hunter, L. (2004). Prevention of anxiety in children and adolescents in a schools setting: The role of school-based practitioners. Children \& Schools, 26, 87-101.

Tortella-Feliu., Servera. M., Balle, M., \& Fullana, M. A. (2004). Viabilidad de un programa de prevención selectiva de los problemas de ansiedad en la infancia aplicado en la escuela. International Journal of Clinical and Health Psychology, 4(2), 371-387. Retrieved from http://www.redalyc.org/articulo.oa?id=33740209

Vostanis, P. (2006). Strengths and difficulties questionnaire: Research and clinical applications. Current Opinions in Psychiatry, 19, 367-372. doi: 10.1097/01. yco.0000228755.72366.05 